\title{
Erythema Dyschromicum Perstans
}

Mahmoud Khalifa Marzouq ${ }^{1}$, Khadiga Ahmed Ismail ${ }^{2,3 *}$, Ahmed Mahmoud Khalifa ${ }^{4}$, Osama Mahmoud Khalifa ${ }^{5}$.

${ }^{1}$ Consaltant of Dermatology and venereology, King Faisal Medical Complex, Taif,Saudi Arabia

${ }^{2}$ Laboratory Medicine Department, Faculty of Applied Medical Sciences, Taif University,Taif,Saudi Arabia

${ }^{3}$ Parasitology Department Faculty of Medicine, Ain-Shams University,Cairo,Egypt

${ }^{4}$ Forencic and Toxicology Department Faculty of Medicine, Ain-Shams University, Cairo,Egypt

${ }^{5}$ Faculty of Medicine, Ain-Shams University, Cairo,Egypt

*Corresponding Author: Khadiga Ahmed Ismail, Faculty of Applied Medical Sciences, Taif University Taif Saudi Arabia. Parasitology Department Faculty of Medicine, Ain-Shams University Cairo Egypt.

Received date: January 11, 2020; Accepted date: January 23, 2020; Published date: January $29,2020$.

Citation: Marzouq K. Mahmoud., Ismail A. Khadiga., Khalifa M Ahmed., Khalifa M. Osama., (2020) Erythema Dyschromicum Perstans.J. Orthopaedics and Surgical Sports Medicine, 3(1): Doi: 10.31579/2641-0427/022

Copyright: () 2020 Khadiga Ahmed Ismail., This is an open-access article distributed under the terms of The Creative Commons Attribution License, which permits unrestricted use, distribution, and reproduction in any medium, provided the original author and source are credited.

\begin{abstract}
Erythema dyschromicum perstans is an asymptomatic eruption of oval, polycyclic, or irregularly shaped, gray-blue hyperpigmented macules on the trunk, the arms, the face, and the neck. It begins as ash-colored macules, sometimes with an erythematous or elevated border. The patient is not usually suffer from any systemic symptoms. Erythema dyschromicum perstans may resolve in 2-3 years in prepubertal children, but it is more likely to persist in adults. [1] Erythema dyschromicum perstans (EDP) most often affects darker skinned patients, most frequently Latin Americans and Indians. It has also been reported in people of lighter skin colour and various ethnicities. It may occur in women more often than men. It is repoted in young adults than adults.

The exact etiology of EDP is unknown. Damage to melanocytes and basal cell keratinocytes that is observed with EDP is due to an abnormal immune response to antigens with a predominance of CD8 + T lymphocytes in the dermis and HLA$\mathrm{DR}+$, intercellular adhesion molecule $1+$ keratinocytes in the epidermis.

EDP is characterized in histological examination by a vacuolar liquefactive degeneration of the basal cell layer with dermal melanosis and a perivascular infiltrate.
\end{abstract}

Keywords: erythema dyschromicum perstans; hyperpigment; cd8 + t lymphocytes; epidermis

\section{Case report}

65 years old Saudi male patient, presented with slow onset of asymptomatic pigmentation in the trunk and less prominent pigmentation in the extremities since few months as shown in plates $[1,2,3,4] . \mathrm{He}$ was under treatment with phenytoin 100 P/O T.I.D. There was no oral pigmentation. There was also no other associated symptoms.

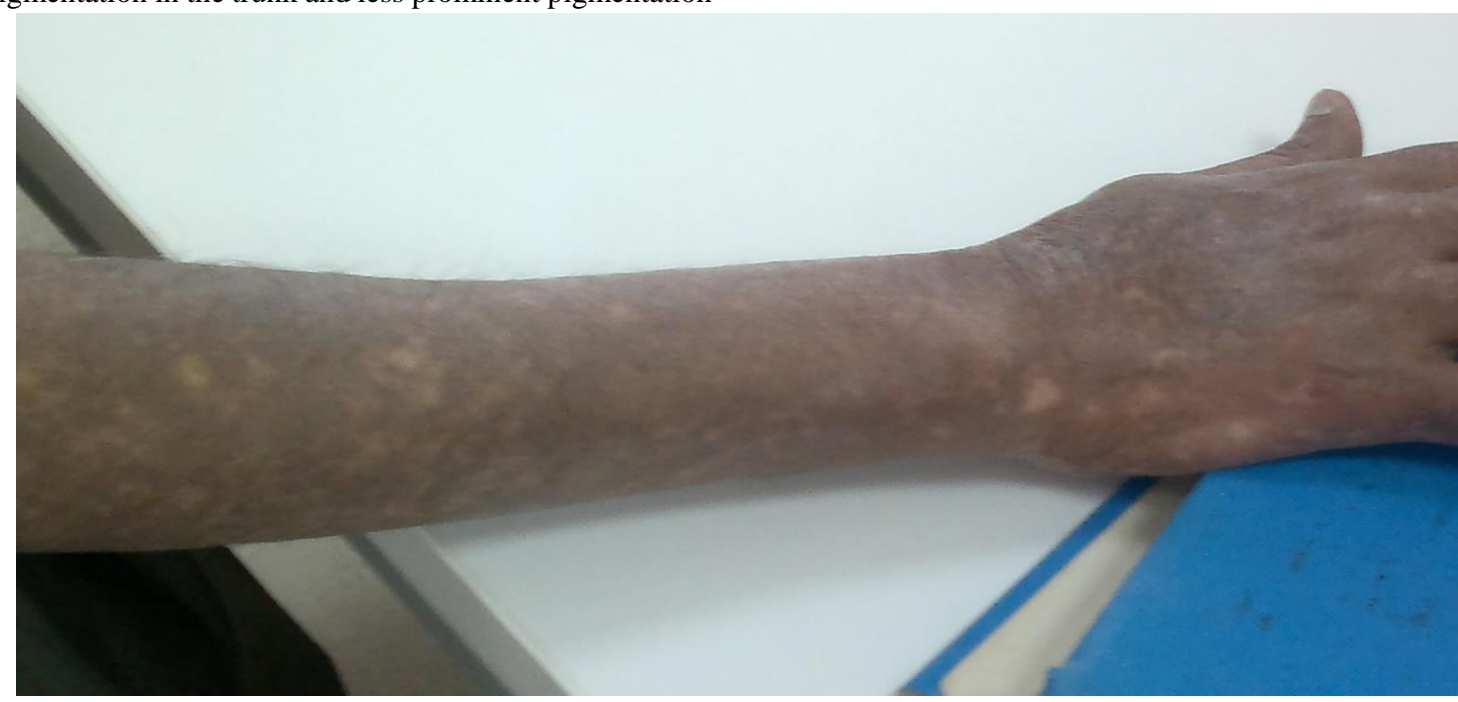

Plate 1: diffuse pigmentation in the right forearm and right hand. 


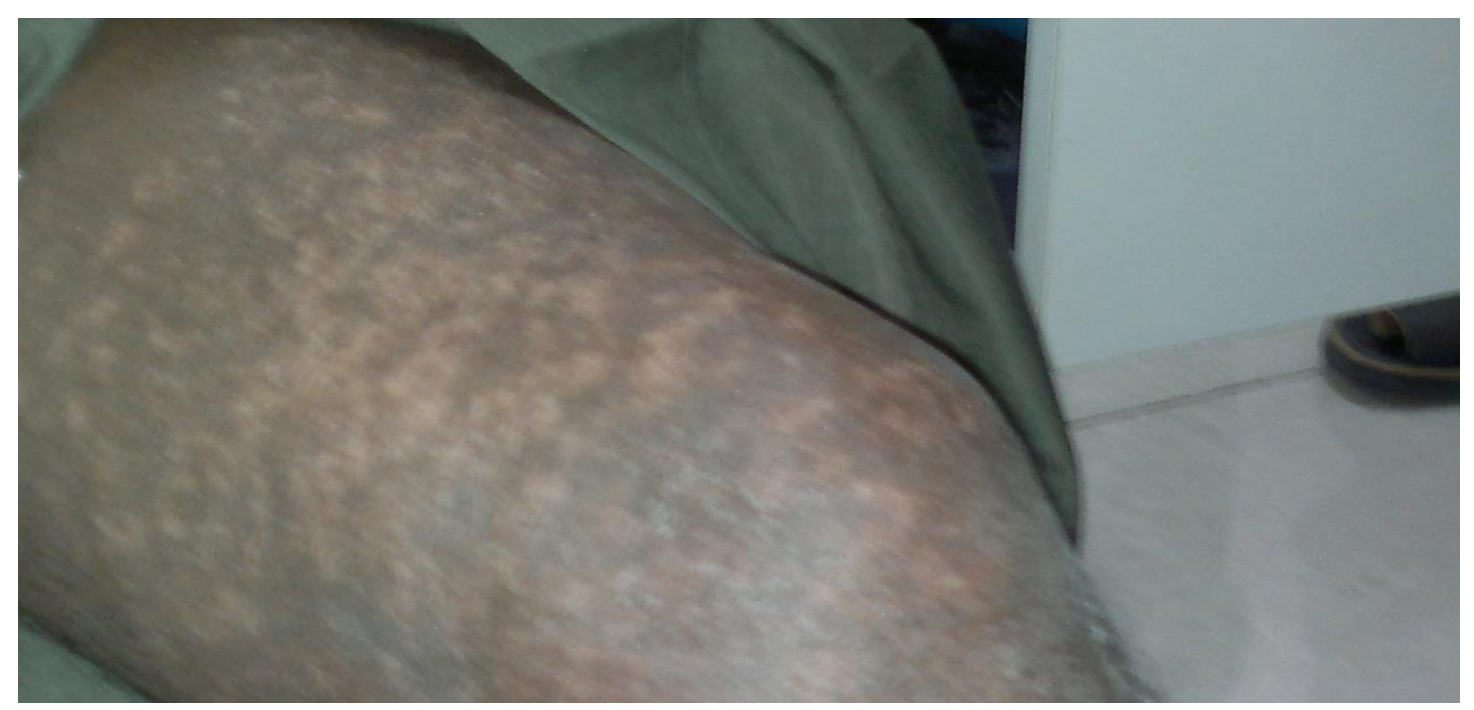

Plate 2: shows pigmentation in the right thigh

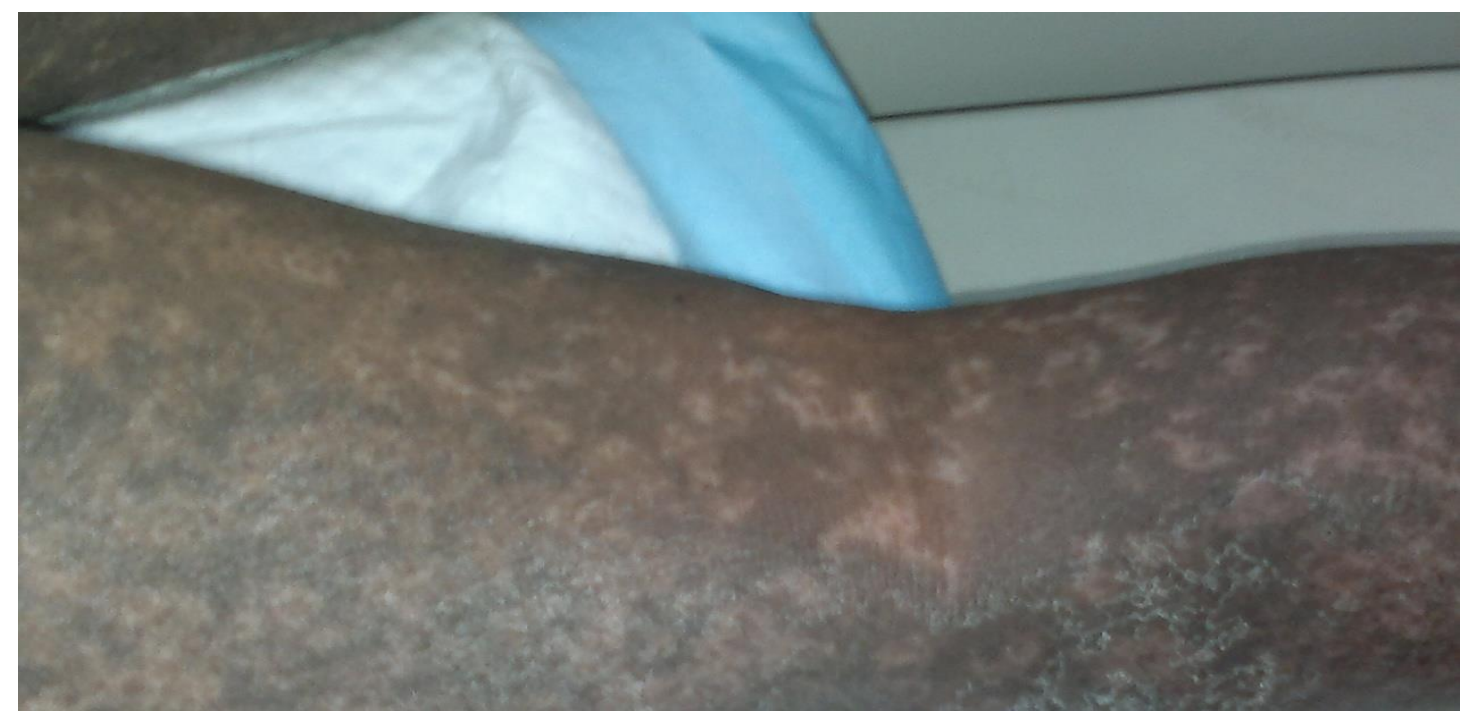

Plate 3: shows pigmentation in the back of the right thigh.

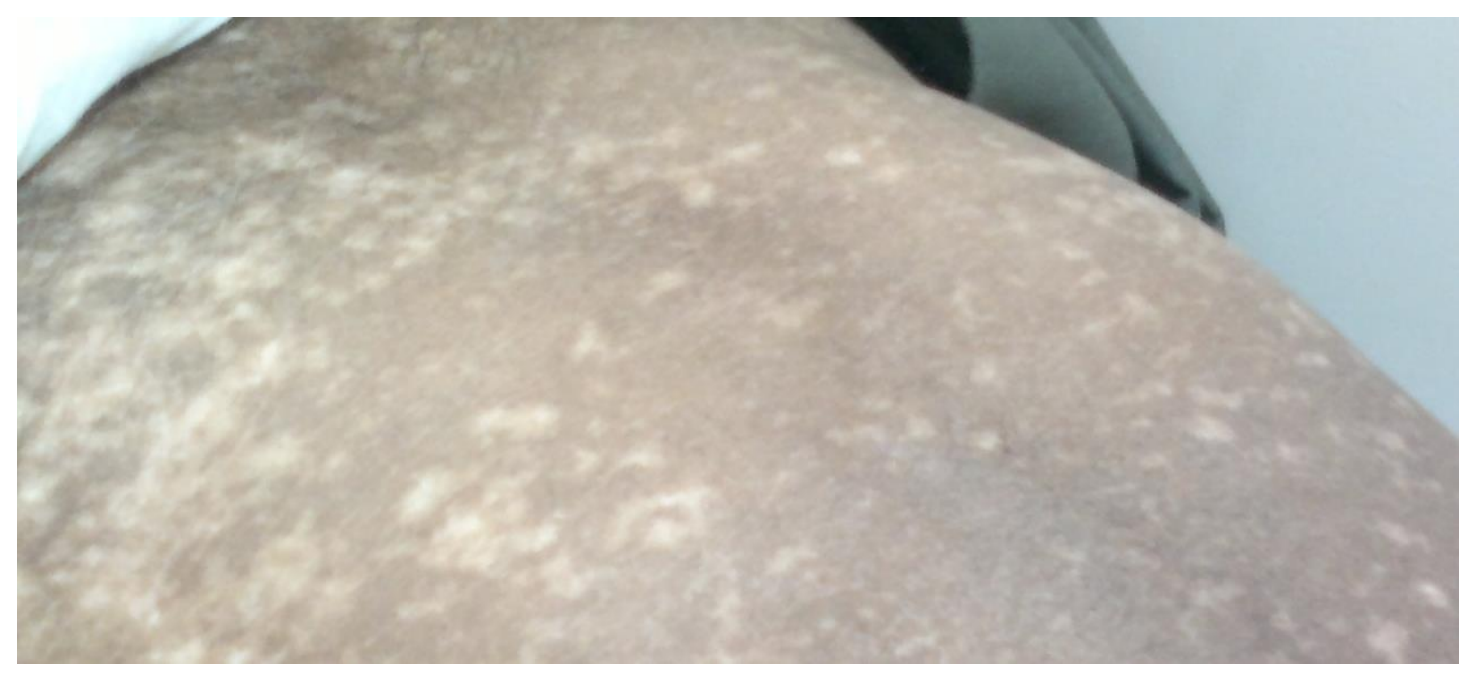

Plate 4: shows scattered normal skin in between pigmented areas 
Laboratory Investigations: As regard his complete blood count:

The clinically significant results are as follows:

White blood cell count (WBC) of $7.70 \mathrm{k} / \mu \mathrm{L}(\mathrm{N})(\mathrm{n} 4-10 \mathrm{k} / \mu \mathrm{L})$, with a eosinophilia of $15.3 \%$ (n 1-6\%), Red blood cell count (RBC) of 4.61 $\mathrm{M} / \mu \mathrm{L}(\mathrm{L})(\mathrm{n} 4.5-5.5 \mathrm{M} / \mu \mathrm{L})$ with a hemoglobin of $12.30 \mathrm{gm} / \mathrm{dl}(\mathrm{L})$, hematocrit of $39.70 \%$ (L) (n 40-50\%), Platelet count of $237 \mathrm{~K} / \mu \mathrm{L}(\mathrm{N})(\mathrm{n}$ $150-410 \mathrm{~K} / \mu \mathrm{L})$.

\section{As regard his chemistry:}

His random glucose of $98.20 \mathrm{mg} / \mathrm{dL}$ (n $70-140 \mathrm{mg} / \mathrm{dL}$ ), blood urea of $13.40 \mathrm{mq} / \mathrm{dL}$ (low) (n 20-48 mq/dL), creatinine of $0.61 \mathrm{mq} / \mathrm{dL}$ (n $0.6-1.2$ $\mathrm{mq} / \mathrm{dL})$, normal SGOT (AST) $(26 \mu / \mathrm{L})(\mathrm{n} 0-42 \mu / \mathrm{L})$, normal SGPT (ALT)
$(17 \mu / \mathrm{L})(\mathrm{n} 0-33 \mu / \mathrm{L})$, normal bilirubin (total) $(0.243 \mathrm{mg} / \mathrm{dL})(\mathrm{n} 0-1.1$ $\mathrm{mg} / \mathrm{dL})$, total protein $(7.93 \mathrm{~g} / \mathrm{dL})(\mathrm{n} 6.6-8.7 \mathrm{~g} / \mathrm{dL})$, chloride $(101 \mathrm{mmol} / \mathrm{L})$ (n 98-107 mmol/L), sodium (135 mmol/L) (n 135-151 mmol/L), potassium $(4.6 \mathrm{mmol} / \mathrm{L})(\mathrm{n} 3.4-5.1 \mathrm{mmol} / \mathrm{L})$, normal prolactin $(275$ $\mu \mathrm{U} / \mathrm{mL}$ ) (n 86-324 $\mu \mathrm{U} / \mathrm{mL})$, testosterone (total) $(3.75 \mathrm{ng} / \mathrm{mL}$ ) (n $2.8-8$ $\mathrm{ng} / \mathrm{mL})$, low cortisol AM. (97 nmol/L) (n 171-536 nmol/L), insulin (23.4 $\mu \mathrm{U} / \mathrm{mL})(\mathrm{n} 2.6-24.9 \mu \mathrm{U} / \mathrm{mL})$, and low vitamine D total $(25 \mathrm{ng} / \mathrm{mL})(\mathrm{n} 30$ $70 \mathrm{ng} / \mathrm{mL})$.

\section{Histological Findings}

Sections examined from skin biopsy showed basket-weave cornified layer, slight epidermal hyperpigmentation, focal vacuolar alteration, subepidermal melanophages, mild perivasular lymphocytes infiltration in the dermis as shown in plate $[5,6,7]$.

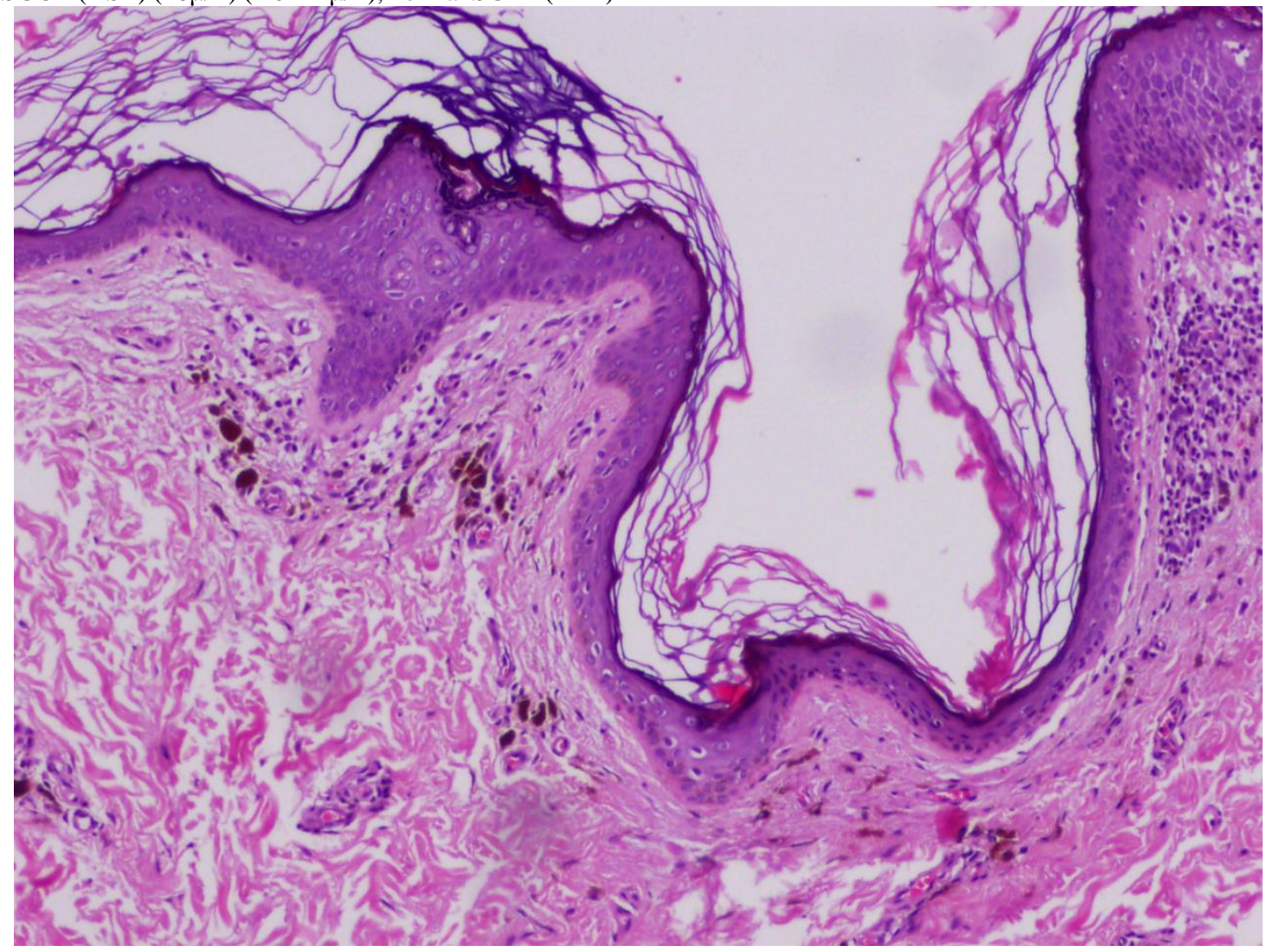

Plate 5: low power magnification shows basket-weave cornified layer, slight epidermal hyperpigmentation, focal vacuolar alteration, sub epidermal melanophages, mild perivascular lymphocytes infiltration in the dermis. 


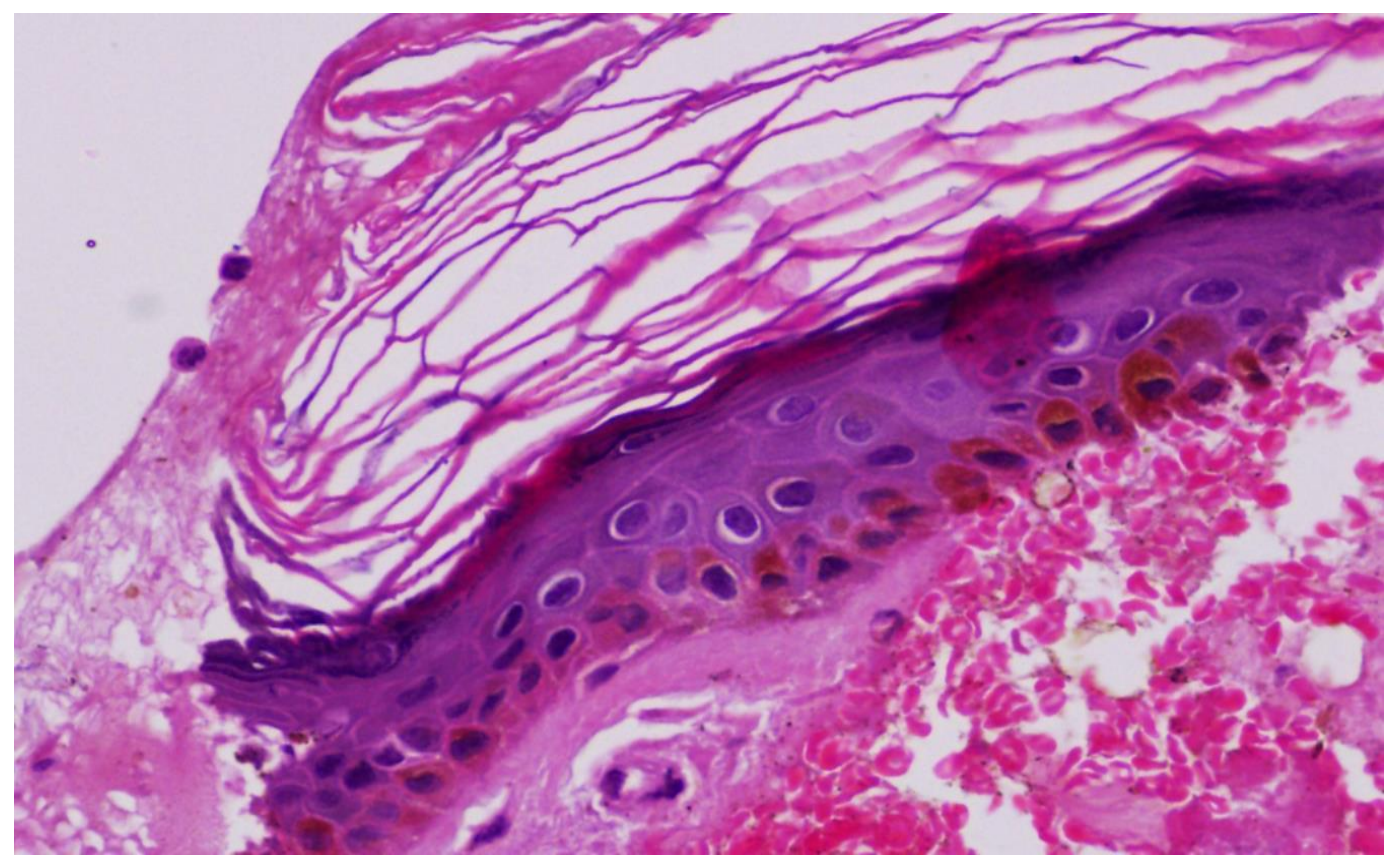

Plate 6: high power magnification of epidermis shows basket-weave cornified layer, slight epidermal hyperpigmentation and focal vacuolar alteration (arrowed).

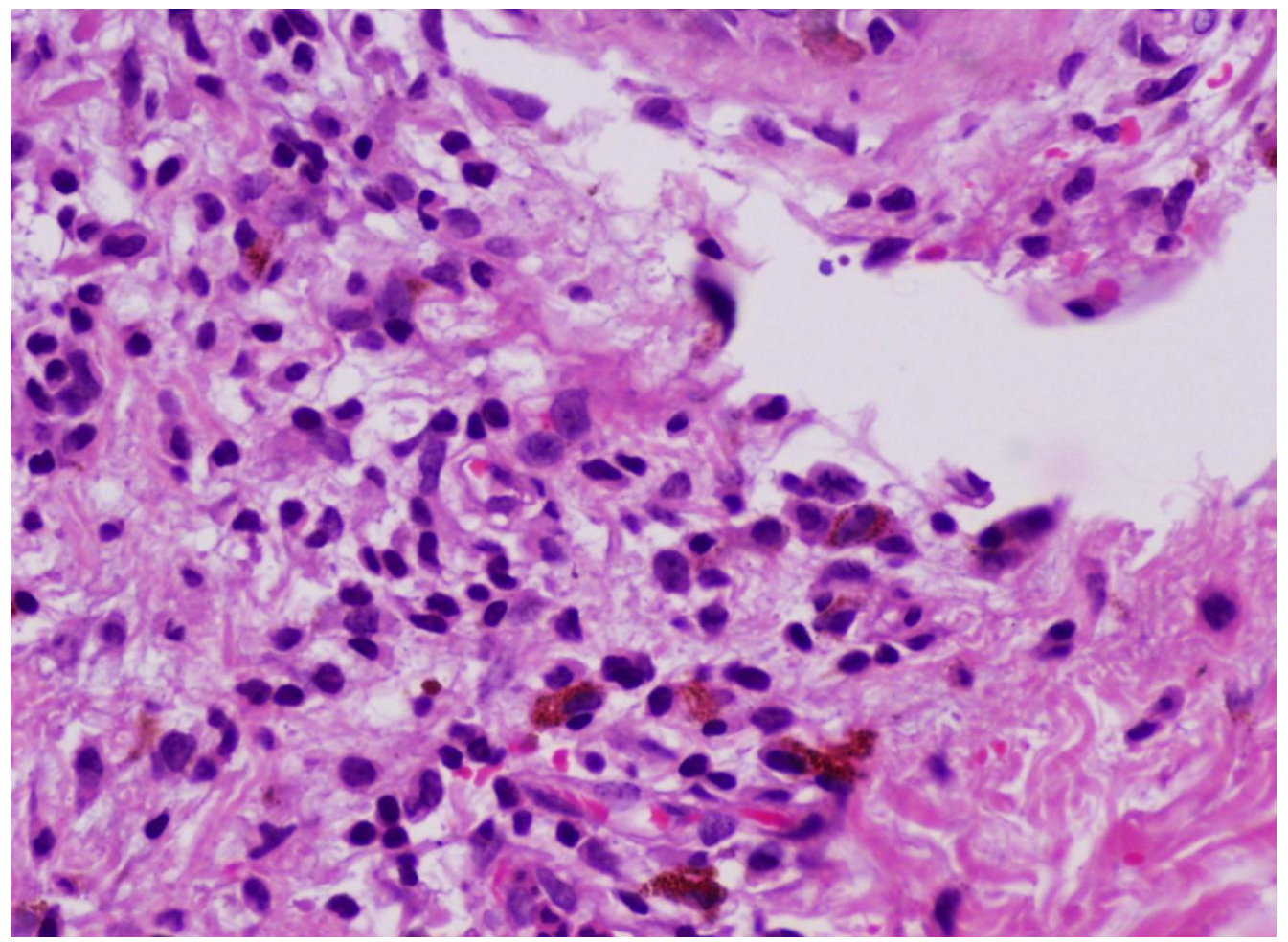

Plate 7: melanophages and perivasular lymphocytes infiltration in the dermis.

\section{Differential diagnosis:}

1- Erythema dyschromicum perstans2- Dermatologic Aspects of Addison Disease

3- Allergic Contact Dermatitis

4- Dermatologic Manifestations of Hemochromatosis

\section{5- Lichen Planus}

1. Erythema dyschromicum perstans

Erythema dyschromicum perstans (EDP) is a pigmentary disorder characterized by multiple pigmented macules on the trunk and proximal extremities. The hallmark of this 
disease is erythema occurring on the border of the pigmented macules. On the other hand, ashy dermatosis (AD) or dermatosis cenicienta is a pigmented condition characterized by persistent ashy hypermelanosis. Although these diseases are often considered to be identical, some clinical features differ. For example, erythema with scaling around the pigmented patch is a characteristic feature of EDP. [11]

The etiology of erythema dyschromicum perstans is unknown, but many consider erythema dyschromicum perstans to be a variant of lichen planus actinicus. A variety of predisposing factors have been cited. These include ingestion of ammonium nitrite, an intestinal parasitosis caused by nematodes (whipworm infection, control of which produced erythema dyschromicum perstans remission), orally administered radiographic contrast media, and, possibly, an occupationally associated cobalt allergy in a plumber. [12]

Histological Findings are usually show mild basal cell layer vacuolar degeneration overlying an upper dermis with a mild perivascular mononuclear cell infiltrate and increased melanophages. [13]

\section{Dermatologic Aspects of Addison Disease}

One of the major finding of Addison disease hyperpigmentation of the skin [2] and mucous membranes, also decreased pubic and axillary hair in women, vitiligo, dehydration, and hypotension. Oral mucous membrane hyperpigmentation is pathognomonic for the disease. [3, 4] Hyperpigmentation of the skin is considered a prominent feature of Addison disease and is present in $95 \%$ of patients with chronic primary adrenal insufficiency. However, hyperpigmentation is not a universal sign of adrenal insufficiency. Although the presence of normal-appearing skin does not exclude the diagnosis.The skin may appear normal, or vitiligo may be present. Increased pigmentation is prominent in areas of the skin that are subject to increased pressure, such as over the knuckles or the skin creases. Hyperpigmentation is also prominent on the nipples, axillae, perineum, and buccal mucosa. [3, 4]

In our case, there is no abnormailty in the electrolyts as in Addison disease as shown in labortatory results.

\section{Pigmented contact dermatitis}

May appear as characteristic erythema, papules, and pruritus associated with epidermal melanosis, with little preexistent actual dermatitis, followed by hyperpigmentation from chemicals in washing materials. [23]

4. Dermatologic Manifestations of Hemochromatosis Around $90 \%$ of patients with idiopathic hemochromatosis had cutaneous hyperpigmentation, although it may be mild. [4] Hyperpigmentation is one of the earliest signs of the disease, and it tends to be most pronounced on sun-exposed skin, particularlyon the face, with a coloration of brownish bronze or, at times, slategrey Structures of skin are injured by iron deposits and increased synthesis of melanin in melanocytes. The rapid tanning with minimal sun exposure reflects the synergistic effects of iron accumulation and sun exposure, but is the result of melanin, rather than the iron itself. Hyperpigmentation often accentuates during exacerbations and regresses with therapy. Treatment with phlebotomy does
immediatelyresolvethehyperpigmentation.[13]

Ichthyosiform alterations, skin atrophy, koilonychia, and hair loss may also be evident. In the series of 100 patients, ichthyosis-like changes were evident in $46 \%$ of patients. [4] Ichthyosiform changes may be mild or marked. Skin affected with ichthyosiform changes is very dry. [13] Cutaneous atrophy was observed in $42 \%$ of 100 patients, usually on the anterior surface of the leg.

Hyperpigmentation of the oral mucosa was found in 15$20 \%$ of patients. Dental pigmentation with enamel loss may be noted. [14] Sanchez-Pablo and coworkers found hyposialia in hemochromatosis-affected patients. [15]

The cutaneous hyperpigmentation in patients with hereditary hemochromatosis should be differentiated from drug-induced hyperpigmentation and actinic reticuloid.

\section{Lichen Planus}

Distinguishing ashy dermatosis from lichen planus pigmentosus (LPP) is not always easy. A Mexican study of 20 patients with erythema dyschromicum perstans and 11 with LPP provided clear clinical delineation between the 2 often histologically indistinguishable disorders. [31] LPP has pruritic brownish black macules or patches, with no active border, on the face and the flexor folds. Erythema dyschromicum perstans does not involve mucosal surfaces, where LPP does. In favor of erythema dyschromicum perstans being either a subset of idiopathic lichen planus or a lichenoid drug eruption are reports of lichen planus and erythema dyschromicum perstans occurring in the same patient, the clinical resemblance of erythema dyschromicum perstans to atrophic lichen planus, and similar histologic patterns with immunofluorescence in both erythema dyschromicum perstans and LPP.

The border of an active erythema dyschromicum perstans lesion and the border of an LPP lesion often both show hyperkeratosis, a thinned epidermis, hydropic degeneration of the basal layer, pigment incontinence, and a perivascular lymphohistiocytic infiltrate. Colloid bodies are occasionally seen in both.

\section{Reference:}

1. Antonov NK., Braverman I., Subtil A., Halasz CL., (2015) Erythema dyschromicum perstans showing resolution in an adult. JAAD Case Rep. 1 (4):185-187.

2. Tienthavorn T, Tresukosol P, Sudtikoonaseth P. (2014) Patch testing and histopathology in Thai patients with hyperpgmentation due to Erythema dyschromicum perstans, Lichen planus pigmentosus, and pigmented contact dermatitis. Asian Pac J Allergy Immunol. 32(2):185-192.

3. Vega ME, Waxtein L, Arenas R, Hojyo T, Dominguez-Soto L. (1992) Ashy dermatosis and lichen planus pigmentosus: a clinicopathologic study of 31 cases. Int J Dermatol. 31(2):90-94.

4. Fussell JNF, Klinger A, Mowad C. (2014) Patchy and diffuse hyperpigmentation. JAAD. . 70:AB118.

5. Lamey PJ, Carmichael F, Scully C. (1985) Oral pigmentation, Addison's disease and the results of screening for adrenocortical insufficiency. Br Dent 20. 158(8):297-298.

6. Shah SS, Oh CH, Coffin SE, Yan AC. (2005) Addisonian pigmentation of the oral mucosa. Cutis. 76(2):97-99. 
7. Chevrant-Breton J, Simon M, Bourel M, Ferrand B. (1977) Cutaneous manifestations of idiopathic hermochromatosis. Study of 100 cases. Arch Dermatol. 113(2):161-165.

8. Hazin R, Abu-Rajab Tamimi TI, Abuzetun JY, Zein NN. (2009) Recognizing and treating cutaneous signs of liver disease. Cleve Clin J Med. Oct. 76(10):599-606.

9. Schemel-Suárez M, López-López J, Chimenos-Küstner E. (2017) Dental pigmentation and hemochromatosis: A case report. Quintessence Int. 48 (2):155-159.

10. Sánchez-Pablo MA, González-García V, Del Castillo-Rueda A. (2012) Study of total stimulated saliva flow and hyperpigmentation in the oral mucosa of patients diagnosed with hereditary hemochromatosis. Series of 25 cases. Med Oral Patol Oral Cir Bucal. 17(1):e45-9.

11. Erythema Dyschromicum Perstans: (2015) Identical to Ashy Dermatosis or Not, Harada K., Tsuboi R., and Mitsuhashi Y. Case Rep Dermatol 7:146-150.

12. Penagos H, Jimenez V, Fallas V, O'Malley M, Maibach HI. (1996) Chlorothalonil, a possible cause of erythema dyschromicum perstans (ashy dermatitis). Contact Dermatitis. 35(4):214-218.

13. Robert A Schwartz, Dirk M Elston, Santiago a Centurion, Michael J Wells, Jeffrey P Callen, et al., 2019. Erythema dyschromicum perstans,
This work is licensed under Creative Commons Attribution 4.0 License

To Submit Your Article Click Here: Submit Manuscript

DOI: $10.31579 / 2641-0427 / 022$
Ready to submit your research? Choose Auctores and benefit from:

* fast, convenient online submission

* rigorous peer review by experienced research in your field

* rapid publication on acceptance

* authors retain copyrights

* unique DOI for all articles

* immediate, unrestricted online access

At Auctores, research is always in progress.

Learn more www.auctoresonline.org/journals/orthopaedics-and-surgicalsports-medicine 